\section{Silvery-thread Moss Control in Creeping Bentgrass Putting Greens with Mancozeb Plus Copper Hydroxide and Carfentrazone Applied in Conjunction with Cultural Practices}

\author{
Steven M. Borst ${ }^{1,4}$, J. Scott McElroy ${ }^{2}$, and Greg K. Breeden ${ }^{3}$
}

AdDitional Index words. Agrostis stolonifera, Bryum argenteum, fertility, population reduction, topdressing, weeds

SuMmary. Carfentrazone is a broadleaf weed control herbicide that is also used for control of silvery-thread moss (Bryum argenteum) in creeping bentgrass (Agrostis stolonifera) putting greens. Field studies were initiated in June 2006 and May 2007 to evaluate silvery-thread moss control with carfentrazone alone, carfentrazone applied with nitrogen (N) and/or topdressing (TD), $\mathrm{N}$ alone, TD alone, and mancozeb plus copper hydroxide. All treatments except for mancozeb plus copper hydroxide and the non-treated control reduced silvery-thread moss populations 16 weeks after initial treatment. Carfentrazone applied alone and carfentrazone followed by $\mathrm{N}$ decreased silvery-thread moss populations by $39 \%$. Carfentrazone followed by TD and carfentrazone followed by $\mathrm{N}+\mathrm{TD}$ decreased silvery-thread moss populations by $73 \%$ and $66 \%$, respectively. These data indicate the importance of using cultural practices to control silvery-thread moss on creeping bentgrass putting greens.

S ilvery-thread moss encroachment is an increasing problem on creeping bentgrass putting greens across the United States (Burnell et al., 2004; Danneberger and Taylor, 1996; Happ, 1998). Silvery-thread moss can be found in many environments such as concrete surfaces, tree roots, compacted soils, cool damp soils, and golf course putting greens (Boesch and Mitkowski, 2005). Once established on a golf course putting green, silvery-thread moss can be difficult to control due to its reproductive nature and anatomy. Silvery-thread mosses are able to reproduce sexually via spores or asexually from displaced fragments (Boesch and Mitkowski, 2005; Nelson, 2007; Yelverton, 2005). These spores and fragments can spread through golf spikes, mowers, or other turf managing equipment.

We thank the Honors Course and the Crossings Golf Club for their assistance with this research.

This research is part of a Master's thesis.

${ }^{1}$ Research Associate, School of Plant, Environmental and Soil Sciences, Louisiana State University Ag Center, Baton Rouge, LA 70803

${ }^{2}$ Assistant Professor, Agronomy and Soils, Auburn University, Auburn, AL 36849

${ }^{3}$ Research and Extension Associate, Plant Sciences Department, University of Tennessee, Knoxville, TN 37996

${ }^{4}$ Corresponding author. E-mail: sborst@agcenter.lsu. edu. ting green, making it more favorable to silvery-thread moss encroachment (Happ, 1998). These stresses and the restriction of mercury-based fungicides have been attributed to the increase in silvery-thread moss infestations observed recently on golf course putting greens (Nelson, 2007; Yelverton, 2005).

Golf course superintendents have tried numerous commercial products and homemade treatments to control silvery-thread moss. Some of these products have been evaluated and numerous trade journals have reviewed their efficacy. Such products include chlorothalonil fungicide, ferrous and ferric sulfates, sodium carbonates such as baking soda, sodium carbonate peroxyhytests, and even dish detergent (Ultra Dawn ${ }^{\circledR}$; Procter \& Gamble, Cincinnati). These treatments are highly variable and often ineffective compared with the use of carfentrazone and mancozeb plus copper hydroxide, both labeled for the control of silvery-thread moss.

Although silvery-thread moss persists on a broad range of soils and surfaces, it does not persist on metal-contaminated sites (Weber and McAvoy, 2003). The sequence of metal toxicity for silvery thread moss has been identified as: mercury $>$ copper $>$ lead $>$ nickel $>$ cadmium $>$ zinc $>$ magnesium (Weber and McAvoy, 2003). With the loss of $\mathrm{Hg}$, $\mathrm{Cu}$-containing pesticides became the focus for silvery-thread moss control.

Junction $^{\circledR}$ (SePRO, Meridian, IN) is a mancozeb-based fungicide labeled for the control of silverythread moss (SePRO Corp., 2006). It is a coordination product of zinc ion, manganese ethylenebisdithiocarbamate, and copper hydroxide. Copper hydroxide comprises $46.1 \%$ (30\% metal equivalent) of the total Junction ${ }^{\circledR}$ (mancozeb plus copper hydroxide) chemistry. The highest labeled rate of $4 \mathrm{oz} / 1000 \mathrm{ft}^{2}(12.2$ $\mathrm{kg} \cdot \mathrm{ha}^{-1}$ ) product weekly would apply copper $(\mathrm{Cu})$ at an equivalent of $5 \mathrm{lb} /$ acre (5.6 kg.ha-1) (SePRO Corp., 2006). Previous research has indicated that five or more applications

\begin{tabular}{llll}
\hline $\begin{array}{l}\text { Units } \\
\begin{array}{l}\text { To convert U.S. to SI, } \\
\text { multiply by }\end{array}\end{array}$ & U.S. unit & SI unit & $\begin{array}{l}\text { To convert SI to U.S., } \\
\text { multiply by }\end{array}$ \\
\hline 0.0929 & $\mathrm{ft}^{2}$ & $\mathrm{~m}^{2}$ & 10.7639 \\
0.0700 & $\mathrm{ft}^{3} / \mathrm{acre}$ & $\mathrm{m}^{3} \cdot \mathrm{ha}^{-1}$ & 14.2913 \\
9.3540 & gal/acre & $\mathrm{L} \cdot \mathrm{ha}^{-1}$ & 0.1069 \\
2.54 & inch $(\mathrm{es})$ & $\mathrm{cm}$ & 0.3937 \\
1.1209 & $\mathrm{lb} / \mathrm{acre}$ & $\mathrm{kg} \cdot \mathrm{ha}^{-1}$ & 0.8922 \\
3.0515 & $\mathrm{oz} / \mathrm{l} 000 \mathrm{ft}^{2}$ & $\mathrm{~kg} \cdot \mathrm{ha}^{-1}$ & 0.3277
\end{tabular}


of copper hydroxide could potentially induce iron deficiency or Cu phytotoxicity in turfgrass plants (Boesch and Mitkowski, 2005; Landschoot et al., 2004). A buildup of $\mathrm{Cu}$ within the root profile can also be detrimental to turfgrass roots. Cook et al. (2002) observed root stunting after applying an equivalent of $293 \mathrm{~kg} \cdot \mathrm{ha}^{-1}$ $\mathrm{Cu}$ over a 1 -year period.

Landschoot et al. (2004) concluded that mancozeb plus copper hydroxide summer treatments did not control silvery-thread moss, but five biweekly fall applications of 7.04 $\mathrm{kg} \cdot \mathrm{ha}^{-1} \mathrm{Cu}$ provided $100 \%$ silverythread moss control when plots were re-evaluated in the spring. Similarly, Cook et al. (2002) found that five to seven biweekly applications of copper hydroxide applied at 4.85 to 7.27 $\mathrm{kg} \cdot \mathrm{ha}^{-1} \mathrm{Cu}$ during cool wet weather between October and March effectively controlled silvery-thread moss.

In 2005 , carfentrazone, a protoporphyrinogen oxidase inhibitor used for the control of a wide range of broadleaf weeds, was labeled for the control of silvery-thread moss on creeping bentgrass putting greens (FMC Corp., 2005; Senseman, 2007). It quickly became the industry standard for silvery-thread moss control on creeping bentgrass putting greens due to its fast, effective, visual control. Numerous trade journal reports concluded that carfentrazone provides efficient control of silvery-thread moss over a broad temperature spectrum (Aylward, 2007; Boesch and Mitkowski, 2005; FMC Corp., 2005; Nelson, 2007; Settle et al., 2006; Yelverton, 2005). Despite all of these reports, no peer-reviewed publications are currently available evaluating carfentrazone control of silvery-thread moss on creeping bentgrass putting greens.

Research was initiated to evaluate silvery-thread moss control on creeping bentgrass putting greens with carfentrazone alone, carfentrazone applied with nitrogen $(\mathrm{N})$ and/or TD, N alone, TD alone, and mancozeb plus copper hydroxide. Increased N and TD treatments were added to this evaluation, as the lack of these practices is often linked with an increase in silverythread moss infestations.

\section{Materials and methods}

Field studies were initiated on 20 June 2006 at the Honors Course
(HC), Ootlewah, TN, and on 21 May 2007 at The Crossings Golf Club (CC), Jonesborough, TN. Studies evaluated silvery-thread moss control with carfentrazone, carfentrazone applied with cultural practices, cultural practices alone, and mancozeb plus copper hydroxide. Putting greens at $\mathrm{HC}$ were built to the U.S. Golf Association (USGA) specifications with a pH of 6.7 (USGA, 2004). Putting greens at CC were constructed as California greens with a $\mathrm{pH}$ of 6.8 (Davis et al., 1990). Creeping bentgrass putting greens at $\mathrm{HC}$ and $\mathrm{CC}$ were mowed daily to a height of $1 / 8$ inch. Total annual $\mathrm{N}$ applied to putting greens at $\mathrm{HC}$ and $\mathrm{CC}$ was 235 and $171 \mathrm{~kg} \cdot \mathrm{ha}^{-1} \mathrm{~N}$, respectively. Research was conducted on naturalized populations of silvery-thread moss contaminating creeping bentgrass putting greens at each location.

Research was conducted in a randomized complete block design and was replicated three times. Treatments included carfentrazone alone at $0.12 \mathrm{~kg} \cdot \mathrm{ha}^{-1}$, carfentrazone followed by TD at $6.5 \mathrm{~m}^{3} \cdot \mathrm{ha}^{-1}$, carfentrazone followed by $\mathrm{N}$ at $12.2 \mathrm{~kg} \cdot \mathrm{ha}^{-1}$, carfentrazone followed by $\mathrm{N}+\mathrm{TD}$, mancozeb plus copper hydroxide alone at $1.8 \mathrm{~kg} \cdot \mathrm{ha}^{-1}, \mathrm{~N}$ alone, TD alone, and $\mathrm{N}$ plus TD. A total of two carfentrazone treatments was applied, at trial initiation and 2 weeks after initial treatment (WAIT). Cultural measures, $\mathrm{N}$, and/or TD were applied at 4 WAIT (2 weeks after the last carfentrazone treatment) and were continued biweekly until 10 WAIT, totaling four applications. Nitrogen applications were made with a $24 \mathrm{~N}-$ 1.7P-9.9K granular greens-grade fertilizer (Pro Source One, Memphis, $\mathrm{TN}$ ) in addition to the total annual inputs of each location. Six mancozeb plus copper hydroxide treatments were applied, beginning at trial initiation, and were continued biweekly until 10 WAIT. Spray applications were applied with a carbon dioxide pressurized backpack sprayer calibrated to 30 $\mathrm{gal} / \mathrm{acre}$ and equipped with $8002 \mathrm{XR}$ TeeJet $^{\circledR}$ (Spraying Systems, Wheaton, IL) flat-fan nozzles. Granular N and TD treatments were applied over each individual plot by hand. Topdressing treatments were brushed into the turf canopy with a push broom. Overhead irrigation was then used to water granular N and TD treatments into the soil profile.
The percentage of silvery-thread moss control was evaluated visually on a $0 \%$ (no control) to $100 \%$ (complete control) scale and was evaluated $3,5,11$, and 16 WAIT. A grid system was used to evaluate total silverythread moss population change within the $1 \times 1-m$ plots. Grids contained 100 intersecting points, if silverythread moss persisted within an intersecting point it would be counted, giving an accurate silvery-thread moss population percentage and eliminating human bias. Grid counts were made at study initiation and at 16 WAIT. Percentage of silvery-thread moss reduction was calculated using the following equation: Percentage of silvery-thread moss population change $=[(\mathrm{b} / \mathrm{a}) \times 100]-100$, where $\mathrm{a}$ is the percentage of silvery-thread moss cover at trial initiation and $b$ is the percentage of silvery-thread moss cover at 16 WAIT. A negative moss population value indicates a silvery-thread moss population reduction where a positive value indicates a silvery-thread moss population increase.

Data were subjected to analysis of variance (ANOVA) at $\alpha=0.05$ using the general linear model procedure in SAS (version 8; SAS Institute, Cary, NC). Variance homogeneity was inspected by plotting residuals and evaluating them for skewing and general disuniformity (Zar, 1999). Neither arcsine nor log transformation improved variance homogeneity; therefore, non-transformed data were used for analysis. Rating dates within a given year were analyzed separately and were not included as a factor in ANOVA. Fisher's protected least significant difference at $\alpha=0.05$ was applied for mean comparisons. Treatment by location interaction was non-significant for all data; therefore, data were pooled over location.

\section{Results and discussion}

VISUAL ASSESSMENT OF SILVERYTHREAD MOSS CONTROL. At no time was creeping bentgrass injury observed with any treatment. No difference was observed among carfentrazone treatments at 3 and 5 WAIT (Table 1). Carfentrazone alone controlled silvery-thread moss $77 \%$ at 3 WAIT. In comparison, mancozeb plus copper hydroxide controlled silvery-thread moss $11 \%$ at 3 WAIT. We observed that carfentrazone applications affected 
surface silvery-thread moss tissue, but would leave a residual silvery-thread moss layer that resembled turfgrass thatch. Given that silvery-thread moss lacks a true vascular system (Crum and Anderson, 1981), contact herbicides such as carfentrazone do not progress throughout the plant (Yelverton, 2005). Therefore, injury is foliar in nature and residual silvery-thread moss can sustain regrowth. Continual carfentrazone applications applied at $0.12 \mathrm{~kg} \cdot \mathrm{ha}^{-1}$ could potentially increase silvery-thread moss suppression, allowing creeping bentgrass to regrow.

Carfentrazone-containing treatments applied with or without $\mathrm{N}$ and/or TD controlled silvery-thread moss $43 \%$ to $67 \%$ at 5 WAIT. At 5 WAIT, only one N and/or TD application had been made. Mancozeb plus copper hydroxide, $\mathrm{N}, \mathrm{TD}$, and $\mathrm{N}+\mathrm{TD}$ treatments controlled silverythread moss $3 \%$ to $13 \%$ at 5 WAIT.

At 11 WAIT, carfentrazone applied with $\mathrm{N}$ and/or TD controlled silvery-thread moss greater than carfentrazone alone. Carfentrazone alone controlled silvery-thread moss $36 \%$, while carfentrazone plus $\mathrm{TD}, \mathrm{N}$, and $\mathrm{N}+\mathrm{TD}$ controlled silvery-thread moss $77 \%, 69 \%$, and $77 \%$, respectively at 11 WAIT. No difference was observed between carfentrazone alone, N, TD, $\mathrm{N}+\mathrm{TD}$, or mancozeb plus copper hydroxide at 11 WAIT. Carfentrazone applied with $\mathrm{N}$ and/or TD controlled silvery-thread moss greater than all other treatments at this rating date, including carfentrazone applied alone.

Topdressing is used on golf greens to control thatch by diluting the organic matter that is generated by decaying leaf matter, stolons, and rhizomes (Turgeon and Vargas, 2006). Visual assessment of the TD plots indicated that along with dilution, abrasion from sand particles also potentially broke up and separated the silverythread moss residual tissue. This potentially would allow carfentrazone to contact more surface area of the moss, increasing carfentrazone efficacy. Increased $\mathrm{N}$ could also promote creeping bentgrass competitiveness, thus leading to greater silvery-thread moss control. Nitrogen treatments increased yearly nitrogen rates at $\mathrm{CC}$ from 171 to $219.8 \mathrm{~kg} \cdot \mathrm{ha}^{-1} \mathrm{~N}$ and $\mathrm{HC}$ from 235 to $283.8 \mathrm{~kg} \cdot \mathrm{ha}^{-1} \mathrm{~N}$. Lower mowing heights and reduced fertility are considered beneficial for increasing putting green speed, but they decrease turfgrass vigor (Nikolai, 2005). Allowing dead silvery-thread moss patches to remain without promoting bentgrass growth increases the chance of silverythread moss recovery.

Carfentrazone alone controlled silvery-thread moss treatments $54 \%$

Table 1. Percentage of visual silvery-thread moss control on creeping bentgrass putting greens using carfentrazone, carfentrazone followed by (fb) nitrogen $(\mathrm{N})$ and/or topdressing (TD), $\mathrm{N}$ and/or TD alone, and mancozeb plus copper hydroxide at 3, 5, 11, and 16 weeks after initial treatment (WAIT).

\begin{tabular}{|c|c|c|c|c|c|}
\hline \multirow[b]{2}{*}{ Treatment $^{\mathrm{z}}$} & \multirow{2}{*}{$\begin{array}{l}\text { Rate }\left(\mathrm{kg} \cdot \mathrm{ha} \mathrm{a}^{-1}\right. \\
\left.\text { or } \mathrm{m}^{3} \cdot \mathrm{ha}^{-1}\right)^{\mathrm{y}}\end{array}$} & \multicolumn{4}{|c|}{ Visual silvery-thread moss control $(\%)^{\mathrm{x}}$} \\
\hline & & 3 WAIT & 5 WAIT & 11 WAIT & 16 WAIT \\
\hline Carfentrazone & 0.12 & 77 & 43 & 36 & 54 \\
\hline Carfentrazone fb TD & $0.12 \mathrm{fb} 6.5$ & - & 63 & 77 & 76 \\
\hline Carfentrazone fb N & $0.12 \mathrm{fb} 12.2$ & - & 54 & 69 & 68 \\
\hline $\begin{array}{l}\text { Carfentrazone } \mathrm{fb} \\
\mathrm{N}+\mathrm{TD}\end{array}$ & $\begin{array}{l}0.12 \mathrm{fb} 12.2 \\
+6.5\end{array}$ & - & 67 & 77 & 78 \\
\hline $\begin{array}{l}\text { Mancozeb plus } \\
\text { copper hydroxide }\end{array}$ & 1.8 & 11 & 13 & 4 & 7 \\
\hline $\mathrm{N}$ & 12.2 & - & 3 & 23 & 32 \\
\hline TD & 6.5 & - & 9 & 25 & 34 \\
\hline $\mathrm{N}+\mathrm{TD}$ & $12.2+6.5$ & - & 10 & 20 & 29 \\
\hline $\mathrm{LSD}_{0.05}{ }^{\mathrm{w}}$ & & 15 & 25 & 32 & 31 \\
\hline
\end{tabular}

${ }^{\mathrm{z}}$ All carfentrazone treatments with or without $\mathrm{N}$ and/or TD were applied twice (trial initiation and 2 WAIT), six mancozeb plus copper hydroxide treatments were applied (trial initiation and 2, 4, 6, and 8 WAIT), and four N and/or TD treatments were applied $(4,6,8$, and 10 WAIT).

${ }^{y}$ Topdressing rates are expressed in cubic meters per hectare. All other treatments are expressed in kilograms per hectare; $\mathrm{l} \mathrm{kg} \cdot \mathrm{ha}^{-1}=0.8922 \mathrm{lb} /$ acre, $\mathrm{l} \mathrm{m}^{3} \cdot \mathrm{ha}^{-1}=14.2913 \mathrm{ft}^{3} /$ acre .

${ }^{x}$ Silvery-thread moss visual control was evaluated for each plot at each timing relative to the non-treated. Numbers were pooled between locations. No cultural practices were applied 3 WAIT, therefore, carfentrazone treatments were displayed as a single mean. All carfentrazone treatments significantly differed from mancozeb plus copper hydroxide treatments.

wFisher's protected least significant difference at $P \leq 0.05$

at 16 WAIT. Carfentrazone applied with $\mathrm{N}, \mathrm{TD}$, and $\mathrm{N}+\mathrm{TD}$ controlled silvery-thread moss $76 \%$, 68\%, and $78 \%$, respectively, at 16 WAIT. In contrast to 11 WAIT, no statistical difference was observed between carfentrazone applied alone and carfentrazone applied with $\mathrm{N}$ and/or TD. Nitrogen, TD, and N + TD controlled silvery-thread moss 32\%, 34\%, and $29 \%$, correspondingly, at 16 WAIT. Carfentrazone applied alone did not differ statistically from $\mathrm{N}$ and/or TD applied alone; however, when these treatments were applied as a combination, silvery-thread moss control increased.

On the final rating date, mancozeb plus copper hydroxide controlled silvery-thread moss 7\%. Mancozeb plus copper hydroxide could potentially have been more effective if applied during fall conditions rather than early summer as it was applied in this research. Landschoot et al. (2004) observed minimal silverythread moss control with mancozeb plus copper hydroxide when applied during summer months; however, applications made in fall provided excellent silvery-thread moss control in the following spring. Previous research has reported the potential for creeping bentgrass chlorosis from five or more mancozeb plus copper hydroxide plus copper hydroxide applications (Landschoot et al., 2004); however, no creeping bentgrass chlorosis was observed at anytime during this study.

S I L VERY - T H RE A D M OS S POPULATION CHANGE. Changes in silvery-thread moss populations were assessed to provide quantitative supplemental data to visual control ratings. All treatments except mancozeb plus copper hydroxide and non-treated control plots decreased silvery-thread moss populations at 16 WAIT (Table 2). Carfentrazone applied alone or with $\mathrm{N}, \mathrm{TD}$, and $\mathrm{N}+\mathrm{TD}$ reduced silverythread moss populations by $39 \%, 73 \%$, $39 \%$, and $66 \%$, respectively. Nitrogen, $\mathrm{TD}$, and $\mathrm{N}+\mathrm{TD}$ reduced silverythread moss populations similar to applications of carfentrazone alone (by $22 \%, 36 \%$, and $23 \%$, respectively). According to Aylward et al. (2007), fertilization and cultural practices are vital for long-term silvery-thread moss suppression.

Silvery-thread moss is a difficult weed species to evaluate visually on 
Table 2. Percentage of silvery-thread moss population change from carfentrazone alone, carfentrazone followed by $(\mathrm{fb})$ nitrogen $(\mathrm{N})$ and/or topdressing (TD), $\mathrm{N}$ and/or TD alone, and mancozeb plus copper hydroxide at the study completion, 16 weeks after initial treatment (WAIT).

\begin{tabular}{|c|c|c|}
\hline Treatment $^{\mathrm{z}}$ & Rate $\left(\mathrm{kg} \cdot \mathrm{ha}^{-1} \text { or } \mathrm{m}^{3} \cdot \mathrm{ha}^{-1}\right)^{\mathrm{y}}$ & $\begin{array}{l}\text { Population } \\
\text { change }(\%)^{\mathrm{x}}\end{array}$ \\
\hline Carfentrazone & 0.12 & $-39^{w}$ \\
\hline Carfentrazone fb TD & $0.12 \mathrm{fb} 6.5$ & -73 \\
\hline Carfentrazone $\mathrm{fb} \mathrm{N}$ & $0.12 \mathrm{fb} 12.2$ & -39 \\
\hline Carfentrazone fb N + TD & $0.12 \mathrm{fb} 12.2+6.5$ & -66 \\
\hline Mancozeb plus copper hydroxide & 1.8 & 35 \\
\hline $\mathrm{N}$ & 12.2 & -22 \\
\hline $\mathrm{TD}$ & 6.5 & -36 \\
\hline $\mathrm{N}+\mathrm{TD}$ & $12.2+6.5$ & -23 \\
\hline Non-treated & & 53 \\
\hline $\operatorname{LSD}_{0.05}{ }^{\mathrm{v}}$ & & 43 \\
\hline
\end{tabular}

${ }^{\mathrm{z}}$ All carfentrazone treatments with or without cultural practices were applied twice (trial initiation and 2 WAIT), six mancozeb plus copper hydroxide treatments were applied (trial initiation and 2, 4, 6, and 8 WAIT), and four N and/or TD treatments were applied $(4,6,8$, and 10 WAIT).

yTopdressing rates are expressed in cubic meters per hectare. All other treatments are expressed in kilograms per hectare; $1 \mathrm{~kg} \cdot \mathrm{ha}^{-1}=0.8922 \mathrm{lb} /$ acre, $1 \mathrm{~m}^{3} \cdot \mathrm{ha}^{-1}=14.2913 \mathrm{ft}^{3} /$ acre .

xercentage of silvery-thread moss population change was calculated by comparing silvery-thread moss populations at the beginning and end of each study. Percentage of silvery-thread moss population change $=[(\mathrm{b} / \mathrm{a}) \times 100]-$ 100 , where $a$ is the percentage of silvery-thread moss cover at trial initiation and $b$ is the percentage of silvery-thread moss cover at 16 WAIT. Numbers were pooled between locations.

"A negative value indicates a silvery-thread moss population reduction where a positive value indicates a silverythread moss population increase.

"Fisher's protected least significant difference at $P \leq 0.05$.

creeping bentgrass putting greens. Changes can be observed in populations with changing environmental conditions. Burnell et al. (2004) observed fluctuations in non-treated plots and attributed it to the ephemeral nature of silvery-thread moss. We observed a $53 \%$ population increase with the non-treated plots. Despite mancozeb plus copper hydroxide applications, silvery-thread moss populations increased 35\%. While there seem to be discrepancies between visual control evaluations and population change evaluations, visual control measurements were rated relative to the nontreated control, and the dynamic nature of silvery-thread moss populations explains these discrepancies. However, as previously mentioned, though treatments appear to injure silvery-thread moss surface tissue, residual tissue was able to sustain regrowth. Therefore, population percentages were better indicators of treatment efficacy.

A healthy turf stand is one of the best ways to prevent silvery-thread moss invasion (Cook et al., 2002). Previous research has attributed increased encroachment to lower mowing heights, reduced fertility, and the elimination of mercury-based fungicides (Burnell et al., 2004; Hummel, 1994; Nelson, 2007; Yelverton, 2005). Any stress applied to the turf resulting in a reduction in stand density and decreased plant vigor can add to the risk of silvery-thread moss encroachment. These data suggest that cultural practices such as $\mathrm{N}$ and TD can aide in the control of silverythread moss on creeping bentgrass putting greens and can provide as much long-term control as carfentrazone applied alone.

\section{Literature cited}

Aylward, A. 2007. Managing moss: A new herbicide proves efficient in ridding greens of those problem clumps, but superintendents must also adhere to important cultural practices for moss control. Golfdom 63:47-48.

Boesch, B. and N. Mitkowski. 2005. Chemical methods of moss control on golf course putting greens. 10 Aug. 2007. $<$ http://www.plantmanagementnetwork. $\mathrm{org} / \mathrm{pub} /$ ats/review/2005/moss/>.

Burnell, K.D., F.H. Yelverton, J.C. Neal, T.W. Gannon, and J.S. McElroy. 2004. Control of silvery-thread moss (Bryum argenteum Hedw.) in creeping bentgrass (Agrostis palustris Huds.) putting greens. Weed Technol. 18:560-565.

Cook, T., B. McDonald, and K. Merrifield. 2002. Controlling moss in putting greens. Golf Course Mgt. 70:103-106.

Crum, H.A. and L.E. Anderson. 1981. Mosses of eastern North America. Vol.
1 and 2. Columbia University Press, New York.

Danneberger, K. and J. Taylor. 1996. Moss on greens: When the rolling stone stops. Golf Course Mgt. 64:53-56.

Davis, W.B., J.L. Paul, and D. Bowman. 1990. The sand putting green: Construction and management. Coop. Ext., Univ. California, Agr. Natural Resources, Oakland, CA.

F.M.C. Corp. 2005. Quicksilver ${ }^{\circledR}$ herbicide product label. FMC Corp., Agr. Products Group, Philadelphia, PA.

Happ, K.A. 1998. Moss eradication in putting green turf. U.S. Golf Assn. Green Section Record 36:1-5.

Hummel, Jr., N.W. 1994. Methods for moss control. A research project outlines ways to reduce the presence of moss on golf course greens. Golf Course Mgt. 62:106, 108-110.

Landschoot, P., J. Cook, and B. Park. 2004. Moss control: New products and strategies. U.S. Golf Assn. Green Section Record 42:7-9.

McCarty, L.B., M.F. Gregg, and J.E. Toler. 2007. Thatch and mat management in an established creeping bentgrass golf green. Agron. J. 99:1530-1537.

Nelson, M. 2007. Of moss and men. 11 Jan. 2008. <http://www.usga.org/turf/ green_section_record/2007/jul_aug/ ofmoss.html>.

Nikolai, T.A. 2005. The superintendent's guide to controlling putting green speed. Wiley, Hoboken, NJ.

Senseman, S.A. (ed.). 2007. Herbicide handbook, 9th ed. Weed Sci. Soc. Amer, Lawrence, KS.

SePRO Corp. 2006. Junction ${ }^{\circledR}$ fungicide/bactericide product label. SePRO Corp, Meridian, IN.

Settle, D.M., R.T. Kane, and G.C. Miller. 2006. Evaluation of newer products for selective control of moss on creeping bentgrass greens. U.S. Golf Assn. Turfgrass Environ. Res. Online 6:1-6. 11 Jan. 2008. <http://usgatero.msu.edu/v06/ n05.pdfs.

Turgeon, A.J. 2008. Turfgrass management, 8 th ed. Pearson Education, Upper Saddle River, NJ.

Turgeon, A.J. and J.M. Vargas, Jr. 2006. The turf problem solver. Wiley, Hoboken, NJ.

U.S. Golf Association Green Section Staff. 2004. USGA recommendations for a method of putting green construction. 15 Dec. 2009. <http://www.usga.org/ course_care/articles/construction/ 


\section{Research Reports}

greens/USGA-RecommendationsFor-A-Method-Of-Putting-GreenConstruction $\% 282 \% 29 />$.

Weber, P.A. and T.O. McAvoy. 2003. Moss infestations in putting greens: Eradication by electromotive destruction of chlorophyll. U.S. Golf Assn. Green Section Record 41:32-36.

Yelverton, F.H. 2005. Managing silvery thread moss in creeping bentgrass greens. Golf Course Mgt. 73:103-107.
Zar, J.H. 1999. Biostatistical analysis. 4th ed. Pearson Education, Upper Saddle River, NJ. 